\title{
ROZWAŻANIA O POWSTANIU WARSZAWSKIM NA ŁAMACH „TYGODNIKA POWSZECHNEGO” W LATACH 1945-1953
}

Streszczenie. Celem niniejszego artykułu było szczegółowe przedstawienie rozważań publicystów „Tygodnika Powszechnego” na temat powstania warszawskiego. W realiach powojennej Polski katolickie spojrzenie prezentowane przez „Tygodnik” było wyraźnie odmienne od promowanego przez ówczesną władzę światopoglądu materialistycznego. Redakcja tego chrześcijańskiego pisma, mimo iż generalnie unikała tematów związanych z losem zwykłych, cywilnych mieszkańców polskiej stolicy podczas tych dramatycznych wydarzeń, nie wahała się poruszać bolesnych tematów. Obszernie potraktowano kwestię religijności walczących i postać Krzysztofa Kamila Baczyńskiego. Choć przy opisie niektórych wątków np. rzekomy udział własowców w walkach, powielano komunistyczne mity w narracji o powstaniu redakcja tygodnika żywo dyskutowała między sobą, ukazując na łamach pisma odmienne światopoglądy (np. polemika między Wojciechem Kętrzyńskim a Stefanem Kisielewskim). W związku z powyższym należy stwierdzić, że "Tygodnik Powszechny" mimo zewnętrznych nacisków podchodził do tematu powstania warszawskiego w możliwie najpełniejszy sposób.

Słowa kluczowe: „Tygodnik Powszechny”, II wojna światowa, powstanie warszawskie, Rzeczpospolita Polska, katolicka prasa.

P owstanie warszawskie trwające od 1 sierpnia 1944 do 2 października 1944 r. wciąż pozostaje jedną z najboleśniejszych i najwrażliwszych kart historii narodu polskiego. Pamięć o unicestwieniu polskiej stolicy i śmierci ok. 136 tys. Polaków ${ }^{1}$ jest do dzisiaj zaskakująco żywa i w wielu

1 J.Z. Sawicki, Bitwa o prawdę. Historia zmagań o pamięć powstania warszawskiego 19441989, Warszawa 2005, s. 11, przyp. 16. Inni badacze przywołują jednak liczbę ok. 200 tys. 
przypadkach wciąż wywołuje silne emocje. Zasadność owego wydarzenia, podejmowane podczas niego decyzje, a także jego skutki do dzisiaj wywołują żywe dyskusje i spory.

Celem poniższego artykułu jest ukazanie odbioru tej tragedii w „Tygodniku Powszechnym" od narodzin pisma w marcu 1945 r. do jego zamknięcia w marcu $1953 \mathrm{r}^{2}$ Zlikwidowanie pisma wynikało z odmowy opublikowania odredakcyjnego pożegnania zmarłego wtedy Józefa Stalina.

„Tygodnik Powszechny” został wybrany ze względu na jego katolicki charakter, niezwykle ciekawy skład redakcji oraz niezwykle silne związki z Kurią Metropolitalną. W pewnych kręgach pismo to, było wręcz odbierane jako nieoficjalny organ ks. bp. Adama Stefana Sapiehy. Dlatego właśnie rozważania o powstaniu warszawskim na łamach „Tygodnika Powszechnego” ukazują nam szerszy, katolicki nurt dyskusji o tragedii bohaterskiego miasta. Dzięki powojennej silnej pozycji Kościoła katolickiego wynikającej ze zmian demograficznych i jego działalności podczas II wojny światowej oraz z faktu, że władza komunistyczna początkowo odsunęła w czasie walkę z Kościołem na rzecz rozprawienia się z zarówno opozycją polityczną (Polskie Stronnictwo Ludowe) jak i zbrojną (żołnierze podziemia antykomunistycznego), na łamach pism katolickich była możliwa pewna wymiana myśli i poglądów. Oczywiście choć owa możliwość była dość mocno ograniczona, stosunkowo niewielka liczba tytułów prasowych mogła sobie na nią pozwolić.

Nie sposób jednak opisać przedstawiania powstania warszawskiego na łamach „Tygodnika Powszechnego" bez wcześniejszej znajomości polityki władzy w stosunku do owego wydarzenia w omawianym okresie. Jak trafnie zauważył Jacek Sawicki, powstanie będąc zrozumiałym symbolem niezależności, miało potencjał do podsycania oporu społecznego ${ }^{3}$. Stało się jasne, że dla przyszłej władzy, sama pamięć o minionym wydarzeniu będzie zagrożeniem. System wobec takiej sytuacji nie mógł być bierny, konieczne stało się podjęcie odpowiednich kroków.

Komunistyczna władza w stosunku do warszawskiego zrywu podjęła następującą taktykę: wprowadzała czczenie „prawomyślnych” bohaterów, czyli osób należących do Armii Ludowej i niewinnych ofiar oraz próbowała „zawłaszczyć” sobie wszystkich zmarłych. Dodatkowo winę za zniszczenie miasta przypisywano dowódcom Armii Krajowej. Ich decyzja była wprost

zabitych. Zob. M. Napiórkowski, Powstanie umarłych. Historia pamięci, Warszawa 2016, s. 60; N. Davies, Powstanie' 44, tłum. E. Tabakowska, Kraków 2014, s. 833.

${ }^{2}$ Niniejszy artykuł jest rozszerzeniem i pogłębieniem podrozdziału mojej niepublikowanej pracy licencjackiej Rozliczenie z II wojnq światowq na łamach „Tygodnika Powszechnego" $w$ pierwszych latach istnienia pisma. Owa praca dyplomowa jest przechowywana w Katedrze Historii Polski i Świata po $1945 \mathrm{r}$.

3 J.Z. Sawicki, Pomnik jako pole bitwy, „Roczniki Nauk Społecznych” 2015, t. 7, nr 3, s. 86. 
nazywana „zbrodnią”, a oni sami zdrajcami. Siły III Rzeszy miały jedynie wykonać podjętą przez akowców decyzję . Warto tu wspomnieć o 47 numerze pisma „Rzeczpospolita: organ Polskiego Komitetu Wyzwolenia Narodowego" z 18 września 1944 r., gdzie w publikowanych artykułach usilnie forsowaną taką wizję wydarzeń jeszcze podczas trwania walk. Jako przykład możemy zacytować przykładowe stwierdzenie znajdujące się już na pierwszej stronie owego numeru:

Po tem jak próba Sosnkowskiego powtórzenia pod okupacją sanacyjnego przewrotu majowego w Warszawie poniosła fiasco, klika Raczkiewicz-BórSosnkowski okazała się oskarżona o nieodpowiedzialne wywołanie przedwczesnego powstania i spowodowanie niewinnych ofiar 5 .

W ten sposób przedstawiano historię jakoby AK miała nie tylko wywołać powstanie, ale i je zdradzić, wchodząc przy tym w kolaborację z Niemcami ${ }^{6}$. Należy zaznaczyć, że propaganda ta była wymierzona w ludzi wahających się w sprawach politycznych, nie mających ugruntowanego poglądu na nową rzeczywistość, w której się znaleźli ${ }^{7}$.

Należy tu wspomnieć o masowo drukowanej broszurze Powstanie w Warszawie. Fakty i dokumenty. Publikacja ta wyznaczyła drogę, jaką przez długi okres PRL-u sukcesywnie podążała oficjalna narracja ${ }^{8}$. By przekonać się o słuszności tego twierdzenia, warto tu przytoczyć część tytułów rozdziałów i podrozdziałów omawianej publikacji: Zbrodnicza gra polityczna, Opinia zagraniczna potępia dowództwo A.K., Działanie na szkodę A.L., Setki ton broni, amunicji i żywności $i^{9}$, Wydanie Niemcom obrońców Żoliborza. Nie omieszkano również wytłuszczać najważniejszych tez propagandowych ${ }^{10}$.

W ramach ukazywania społeczeństwu „słusznych” bohaterów tworzono silny kontrast między dowódcami AK a członkami sztabu Armii Ludowej, zabitymi podczas walk. Ci drudzy znajdowali się w zbombardowanym przez Niemców budynku. Propaganda nagłaśniała maksymalnie owe wydarzenie „przykrywając” śmierć tysięcy mających odmienne poglądy akowców. Naturalnie nie przeszkodzi to $\mathrm{w}$ dalszych sugestiach, że powstańcze masy myślały tak jak polegli alowcy ${ }^{11}$.

${ }^{4}$ M. Napiórkowski, dz. cyt., Warszawa 2016, s. 91-92, 96; J.Z. Sawicki, Bitwa o prawdę..., s. 30.

5 Panowie w Londynie radzili..., „Rzeczpospolita: organ Polskiego Komitetu Wyzwolenia Narodowego" 1944, R. 1, nr 47, s. 1.

${ }_{6}$ M. Napiórkowski, dz. cyt., s. 100.

${ }^{7}$ J.Z. Sawicki, Bitwa o prawdę..., s. 31.

8 Tamże, s. 27.

${ }^{9}$ Naturalnie od Sowietów.

${ }_{10}$ Powstanie w Warszawie. Fakty i dokumenty, b.m.w. 1945.

11 M. Napiórkowski, dz. cyt., s. 93-94; J.Z. Sawicki, Bitwa o prawdę..., s. 29. 
Dla oficjalnej, komunistycznej wizji warszawskich wydarzeń, pierwszym ciosem okazała się kwestia zwłok. Ciała po powstaniu nie były grzebane, aż do stycznia 1945 r. Liczba ciał w oczywisty sposób obnażała komunistyczne twierdzenia jakoby w powstaniu miała brać udział jedynie garstka antypolskich szaleńców. Należy również zwrócić uwagę, że sam udział w uroczystościach pogrzebowych, był odbierany jako swoista deklaracja stosunku do nowej władzy ${ }^{12}$.

Dzięki wielu niezależnym inicjatywom oddolnym społeczeństwo niejako wymusiło na władzy podjęcie pierwszych obchodów rocznicy powstania. Jednakże specjalnie utworzony Stołeczny Komitet Obchodu Pierwszej Rocznicy Powstania Sierpniowego w Warszawie zorganizował wszystkie uroczystości w sposób eksponujący „jedyną słuszną” wizję powstania. Każda obecna na owych wydarzeniach osoba, musiała zetknąć się z oficjalną retoryką ${ }^{13}$.

Podczas drugiej rocznicy z inicjatywy środowiska antysystemowego, zebranego wokół osoby pułkownika „Radosława” ${ }^{14}$, wybudowano w sposób półlegalny pomnik Gloria Victis na cmentarzu powązkowskim ${ }^{15}$.

Warto tu również wspomnieć o pomniku poświęconemu tragedii stolicy jaki powstał w Słupsku w 1945 r. To dzieło sztuki zostało ponownie odsłonięte 15 września 1946 r. po dobudowaniu kompozycji figuralnej autorstwa Jana Malety. Rzeźbę tę oficjalnie zatytułowano Bohaterom Powstania Warszawskiego, by zminimalizować ryzyko ingerencji władz ${ }^{16}$.

Należy tu wspomnieć, że po umocnieniu swojej pozycji w wyniku referendum z 30 czerwca 1946 r. retoryka komunistów uległa znacznej intensyfikacji, mimo to jednak obchody drugiej rocznicy były wydarzeniami jeszcze stosunkowo głośnymi. Powodem takiego stanu rzeczy, była legitymizacja władzy Partii, przez ukrywanie sposobu jej uzyskania oraz ukazywanie siebie jako oswobodzicieli ${ }^{17}$.

Od roku 1947 do końca roku 1948 rozpoczęto swoisty proces „wyciszania" tematu powstania. W czasie bliskim kolejnym rocznicom, w prasie ograniczano i/lub całkowicie eliminowano miejsce poświęcone na wspomnienie

12 M. Napiórkowski, dz. cyt., s. 9.

13 Tamże, s. 154-156.

14 Jan Mazurkiewicz „Radosław” - ur. 27 sierpnia 1896 r. - zm. 4 maja 1988 r. Oficer służby stałej piechoty WP Od 1 lutego 1944 dowódca Kierownictwa Dywersji Komendy Głównej Armii Krajowej, podczas powstania warszawskiego dowódca zgrupowania „Radosław”. Po II wojnie światowej stał na czele Komisji Likwidacyjnej b. AK. 4 lutego 1949 r. aresztowany, skazany na dożywotnie więzienie, zwolniony w wyniku amnestii w 1956 r., zrehabilitowany w 1957 r. Zob.: https://www.1944.pl/powstancze-biogramy/jan-mazurkiewicz,30532.html (dostęp: 1.12.2020).

15 Zob. M. Napiórkowski, dz. cyt., s. 181-185.

16 J.Z. Sawicki, Pomnik jako pole..., s. 91.

17 Tenże, Bitwa o prawdę..., s. 59, 63. 
tragicznego losu stolicy. Zamiast tego „raczono” społeczeństwo historiami o np. bohaterskich przodownikach pracy ${ }^{18}$. Cel wyciszenia powstania został osiągnięty - w roku 1948 warszawskie cmentarze stały się jedynym miejscem celebracji pamięci tragicznych wydarzeń ${ }^{19}$.

Pod koniec 1948 r. strategia walki z pamięcią o zrównaniu polskiej stolicy z ziemią stała się niezwykle bezlitosna, brutalna i bezpośrednia. Na przełomie lat 1948/1949 doszło do aresztowania najważniejszych działaczy komitetów ekshumacyjnych. Część osób aresztowanych, jak np. Jan Rodowicz „Anoda”, nie przeżyła śledztwa. Po tych wydarzeniach sam fakt przebywania w pobliżu pomnika Gloria Victis mógł skończyć się aresztowaniem przez funkcjonariuszy Urzędu Bezpieczeństwa ${ }^{20}$. Dodatkowo w okresie stalinizmu sam fakt udziału w powstaniu warszawskim mógł w skuteczny sposób zablokować dalszą karierę. Jednakże, po śmierci Józefa Stalina władze zaczęły luzować swoją politykę historyczną, dotyczącą tego wydarzenia. Już w 1954 temat powrócił do przestrzeni publicznej, choć naturalnie znów przedstawiano jedynie komunistyczną wizję zagłady stolicy ${ }^{21}$.

Tematyka dotycząca tragicznych wydarzeń z powstania 1944 r. pojawiła się na łamach „Tygodnika Powszechnego” bardzo wcześnie, bo już 6 maja 1945 r. Warte wspomnienia jest to, że po raz pierwszy temat ten nie został podjęty w tekście, który byłby próbą oceny czy generalnej analizy powstańczych wydarzeń. Można założyć, że według publicystów „Tygodnika” od powstania minęło za mało czasu, aby już w pierwszych numerach pisma podjąć się napisania takiego ambitnego tekstu. Uważano, że czytelnicy zwyczajnie potrzebowali czasu, aby móc spojrzeć na powstanie, a zwłaszcza jego klęskę, szerzej i dostrzec jej właściwe rozmiary ${ }^{22}$. We wspomnianym wydaniu z 6 maja pojawił się tylko „pisany na gorąco” wiersz Marty Dembicz, Modlitwa warszawska 1944. Utwór ten powstał we wrześniu 1944 r. w Pruszkowie. Daje się z niego odczuć, ciężką i krwawą, atmosferę towarzyszącą powstaniu, przenikającą się ze świadomością, że jedyne, co może odmienić sytuację walczących to cud.

Kolejne wypowiedzi o powstańczych wydarzeniach również nie zawierają ocen, a ich autorzy ograniczają się do mówienia o powstaniu wyłącznie jako o tragedii setek tysięcy ludzi i olbrzymich stratach materialnych, a zwłaszcza w dobrach kulturalnych ${ }^{23}$.

18 M. Napiórkowski, dz. cyt., s. 195-198.

19 Tamże, s. 198.

20 A.K. Kunert, W majestacie „prawa” PRL, „Tygodnik Solidarność” 1997, R. 10, nr 31, s. 12-13; M. Napiórkowski, dz. cyt., s. 200, 212.

${ }^{21}$ J.Z. Sawicki, Bitwa o prawdę..., s. 86, 94.

22 M. Jarczyńska, Powrót, TP 1945, R. 1, nr 30, s. 4.

${ }^{23}$ K. Krobicki, Odrodzenie przez ból, TP 1945, R. 1, nr 10, s. 2-3; M. Morstin-Górska, Minie zima - śniegi [wiersz bez tytułu], TP 1945, R. 1, nr 14, s. 3. 
Pewna zmiana nastąpiła $\mathrm{w}$ okolicach pierwszej rocznicy powstania - 29 lipca 1945 r., wtedy głos zabrała redakcja, odcinając się jednak od komentowania aspektu politycznego wydarzeń z Warszawy począwszy do 1 sierpnia 1944 r. Powodem tego wystąpienia, według stosownej deklaracji, była zbyt mała wiedza społeczeństwa polskiego na temat powstania. Redaktorzy „Tygodnika”, podając wiele informacji faktograficznych, patrzyli na narodowy zryw jako na akt bohaterstwa zbiorowego, znacznie różniącego się od oglądanych podczas okupacji wielu innych aktów bohaterstwa jednostek i mniejszych grup. Szczególny nacisk kładziono na jedność narodu podczas walk, co kłóci się z treścią, niektórych przywoływanych pamiętników ${ }^{24}$. Zespół „Tygodnika” znalazł i wyeksponował pozytywy zaistniałej sytuacji - otóż za sprawą bohaterstwa powstańców i ludności cywilnej Warszawy cały świat miał usłyszeć „krzyk zadręczonego na śmierć narodu”, odpowiadając na jego walkę nie tylko podziwem, ale i pomocą ${ }^{25}$.

Dalej jednak temat powstania komentowano za pośrednictwem wierszy, odmalowując zniszczenia miasta i martyrologię ludności. Wśród publikowanej powstańczej poezji dalekowzroczną wymowę ma utwór Marii Kretuskiej, Warszawa, zawierający profetyczną wizję, że kiedyś nadejdzie czas, gdy bez nienawiści i groźby nowej wojny Polacy będą wspominać o powstaniu ${ }^{26}$.

Z czasem pojawiły się inne formy dziennikarskich wypowiedzi na temat powstania. Nie unikano w nich tak delikatnych tematów jak udział w walkach dzieci, niedożywienie powstańców, zabijanie rannych warszawiaków przez hitlerowców, celowe niszczenie szpitali. Daje się również dostrzec przekonanie, że „zginęli najlepsi”. Takie stwierdzenie jednak nie prowadziło do rozpaczy, a do wniosków, że poległe z bronią w ręku elity należy zastąpić, a zadanie to siłą rzeczy przypada właśnie tym, którzy mieli szczęście przeżyćc ${ }^{27}$.

Nie stroniono również od znacznie mniej chwalebnych wątków. Poruszano temat ratownictwa medycznego podczas walk. Szpitale w dalszych

${ }^{24}$ E. Szumańska, Szkice z powstania, TP 1945, R. 1, nr 19, s. 6; A. Gołubiew, Myśli o powstaniu warszawskim, TP 1946, R. 2, nr 31, s. 1-2; Sanitariuszka „Zosia”, Z Czerniakowa do Śródmieścia (Fragment Pamiętnika), TP 1948, R. 3, nr 32, s. 8-9.

${ }_{25}$ Rocznica warszawskiego powstania, TP 1945, R. 1, nr 19, s. 1.

${ }^{26}$ J. Zagórski, Warszawa latem, TP 1945, R. 1, nr 19, s. 1; S. Marczak-Oborski, Miastu, TP 1945, R. 1, nr 19, s. 2; M. Kretuska, Warszawa, TP 1945, R. 1, nr 19, s. 2; A. Rymkiewicz, List do emigranta, TP 1945, R. 1, nr 27, s. 1.

27 J. Dobraczyński, Nieznany syn, TP 1945, R. 1, nr 19, s. 5; H. Malewska, Rocznica, TP 1945, R. 1, nr 19, s. 5; W. Kętrzyński, Warszawa 1944, TP 1945, R. 1, nr 21, s. 1; M. Jarczyńska, Perspektywy (wrażenia z teatrów), TP 1945, R. 1, nr 34, s. 6; taż, Nocny patrol, TP 1945, R. 1, nr 37, s. 2; B. Włodarz, Obrona Mokotowa (Urywki z pamiętnika pisanego podczas powstania), TP 1949, R. 5, nr 31, s. 6-7. 
dniach powstania z miejsc gdzie można było otrzymać pomoc medyczną stawały się miejscami służącymi do „składania rannych pozbawionych opieki, lekarstw i żywności". Po prostu sanitariuszy i materiałów opatrunkowych było za mało by pomóc wszystkim pokrzywdzonym. Nie stroniono od drastycznych opisów rzeczywistości wynikającej z braku materiałów medycznych i przemęczenia sanitariuszy:

Przeważnie ranni leżą jeden na drugim, byle jak, tak jak im się cisnęło na ziemię kawałek materaca lub koca. Nie obchodzą już nikogo, nikt się nimi nie zajmuje. Bo cóż zresztą można im pomóc, jeśli materiał sanitarny na sto kilkadziesiąt osób stanowi parę opatrunków osobistych, jeżeli nie ma lekarstw, zastrzyków, nie ma dla rannych opatrunków na zmianę, nie ma jedzenia ani picia. Z zupełną wręcz obojętnością słuchamy ich jęków i krzyków, jesteśmy wszystkie bezsilne, załamane, wykończone.

Nawet gdy ktoś faktycznie opatrywał jakiegoś nieszczęśnika, często robił to tylko po to, by go zbyć. Mimo tej dramatycznej sytuacji zdarzały się jednak chlubne jednostkowe wyjątki ${ }^{28}$. Nie zmienia to jednak faktu, że wielu poszkodowanych ludzi zostawiano po prostu samych sobie.

Stan psychiczny ludzi, również pozostawiał wiele do życzenia. Apatia skrajne przemęczenie, depresja, kłótliwość dotknęły większość Polaków przebywających w stolicy ${ }^{29}$.

Zwracano uwagę, że ze względu na niesamowicie zróżnicowane motywacje powstańców, wielu z nich podejmowało walkę z niezbyt patriotycznych, chlubnych pobudek. Wielu z nich nie było ludźmi szlachetnymi - „Byli wśród nas ludzie, spaczeni, cynicy, alkoholicy, lub ci, którzy walczyli tylko dla zemsty - tacy oczywiście rozumowali inaczej"30. To właśnie żołnierze najdłużej posiadali chleb, zaś wymieniać mieli go tylko na wysokoprocentowy alkohol ${ }^{31}$. Zwracano również uwagę na głód i pragnienie wśród walczących. By zaspokoić potrzebę napicia się, zdarzały się przypadki spożywania części zaopatrzenia apteczek, np. denaturatu lub wody utlenionej, nie mówiąc już o jedzeniu trujących owoców czarnego bzu ${ }^{32}$.

${ }^{28}$ M.A. Wasilewski, „Rafał” w powstaniu, TP 1947, R. 3, nr 20, s. 5-7; Sanitariuszka „Zosia”, Z Czerniakowa do Śródmieścia (Fragment pamiętnika), TP 1948, R. 4, nr 31, s. 3-4.

29 Sanitariuszka „Zosia”, Z Czerniakowa do..., s. 3-4; B. Włodarz, Obrona Mokotowa (Urywki...), s. 6-7.

30 Tenże, Katolicyzm powstańców warszawskich, TP 1947, R. 3, nr 31, s. 4.

31 B. Włodarz, Obrona Mokotowa (Urywki...), s. 6-7.

32 Sanitariuszka „Zosia”, Z Czerniakowa do..., s. 3-4; taż, Z Czerniakowa do Śródmieścia (Fragment Pamiętnika), TP 1948, R. 3, nr 32, s. 8-9; B. Włodarz, Obrona Mokotowa (Urywki...), s. 6-7. 
Stosunek ludności cywilnej do powstańców został ukazany w sposób prawie jednoznacznie negatywny, często miało dochodzić między nimi do konfliktów. Przytoczono opis niemalże rywalizacji między żołnierzami AK a cywilami, o to kto szybciej będzie w stanie wyciągnąć kawałki mięsa z końskiego truchła będącego pod ostrzałem. Zdarzały się sytuacje, gdy nie biorący udziału w walkach warszawiacy nie chcieli wpuścić do piwnic walczących, chcąc unikać „bandytów z AK”, tłumacząc następnie Niemcom, że wyjście z ukrycia uniemożliwiały im... oddziały $\mathrm{AK}^{33}$.

Całkowicie osobną kwestią jest stosunek powstańców do religii. Twierdzono, że większa część powstańców była wyznania rzymskokatolickiego, jednak sama "głębokość” wiary była już zróżnicowana. Mimo to pisano, że dla żołnierzy AK modlitwa była wręcz obowiązkiem, zaś mimo iż tematów religijnych w szerszym gronie unikano, to msze polowe były oblegane. Sytuacja zmieniała się diametralnie $w$ mniejszych grupach, gdzie wierzący żołnierze starali się nawracać swoich ateizujących kolegów lub sami toczyli dysputy religijne. Ludność cywilna, również często „uciekała” w modlitwę, znajdując w niej pewne ukojenie. Interesująca jest zmiana jaka zaszła w stosunku do religii wśród walczących Polaków po zakończeniu powstania. Otóż część z wcześniej wierzących ludzi miała stać się ateistami, zaś część niewierzących miała się nawrócić. Pojawiały się nawet stwierdzenia, że Warszawa podczas walk stała się obozem krzyżowców ${ }^{34}$. Jednym z czynników kształtującym takie opinie był z pewnością stosunek Niemców do księży w ogarniętym walką mieście. Byli oni nazywani „największymi bandytami”35.

Mimo tego wszystkiego zwrócono też uwagę na przebłyski normalności podczas opisywanych wydarzeń. Niektórzy ludzie, mieli nawet możliwość pójścia do kina, dawnego niemieckiego Helgolandu, by zobaczyć filmowy reportaż z walk powstańczych. Dzięki poświęceniu filmowców, którzy byli wysunięci na niemalże pierwszą linię starć, miało powstać dzieło na miarę ówczesnych, profesjonalnych kronik wojennych. Owa niezwykła produkcja miała ukazywać żołnierzy AK niemalże jak dobrze zaopatrzoną, regularną armię, co niezwykle mocno kontrastowało z prowizoryczną, pełną wszelkiego rodzaju braków zaopatrzeniowych rzeczywistością. Kolejny dysonans pojawił się w głowie samego autora tekstu, który jak sam wspomina, nie mógł się cieszyć z ukazywanych zwycięstw, branych do niewoli przeciwników i radujących się powstańców. Powodem jego braku radości była

\footnotetext{
${ }^{33}$ Sanitariuszka „Zosia”, Z Czerniakowa do..., s. 3-4; taż, Z Czerniakowa do..., s. 8-9.

${ }^{34}$ M.A. Wasilewski, Katolicyzm powstańców warszawskich..., s. 4; B. Włodarz, Obrona Mokotowa (Urywki...), s. 6-7.

35 W. Graliński, Na starym mieście (Urywek z pamiętnika 8 VIII 1944), TP 1949, R. 5, nr 32, s. 5.
} 
znajomość ostatnich polskich porażek w walkach o stolicę. Niestety mimo wylewającego się z ekranu patosu, zarówno sam film, jak i wielu jego bohaterów oraz widzów nie przeżył powstania ${ }^{36}$.

Jeśli chodzi o poszczególne jednostki biorące udział w walkach, ekipa „Tygodnika Powszechnego” miała wręcz wyjątkowy stosunek do Krzysztofa Kamila Baczyńskiego. Omijając kwestię niezwykle częstego przywoływania dzieł jego autorstwa ${ }^{37}$, poeta ten był wspominany jako osoba niezwykle wyrozumiała, braterska, lubiana. Był jednym z tych przełożonych, którego polecenia były wykonywane entuzjastycznie, bez jakichkolwiek wątpliwości. Miał wyróżniać się jako dowódca, również podczas walki, swoim rozsądkiem i opanowaniem. Podziw i sympatię budziła również jego żona, która sama miała być zaangażowana w prace konspiracyjną, wspierając swojego męża. Żołnierze AK, mieli nawet śpiewać o niej piosenkę: O Barbaro. Pojawiały się również twierdzenia, że mimo jego przedwczesnej śmierci, jego poezja stała się nieśmiertelna ${ }^{38}$.

Jedyny artykuł pokazujący walkę podczas powstania w sposób beletrystyczny, to tekst Jana Dobraczyńskiego ${ }^{39}$ o zniszczeniu wrogiego czołgu dzięki broni otrzymanej ze zrzutu. Do śmierci młodych powstańców, która wiązała się z tym faktem, autor podchodził w sposób do bólu „techniczny”, nie okazując większych emocji, nie mówiąc już o patetyzmie ${ }^{40}$.

Niejako w obronie sensu powstania stanął Wojciech Kętrzyński ${ }^{41}$ w swoim artykule Warszawa 1944. Przywołał on ciekawe argumenty o rzekomym wcześniejszym „spokoju miasta”. Wysuwa opinię, że walki musiały wybuchnąć, czy to przez irracjonalne rozumienie przez Polaków takich wartości jak honor i suwerenność, czy przez świadomą postawę ludności stolicy. Nie zaprzeczał, że walka była beznadziejna, lecz stawiał opinię, że bez

${ }^{36}$ L. Prorok, Powstanie na taśmie filmowej, TP 1947, R. 3, nr 31, s. 3-4.

37 Np.: K. Baczyński, Rzeczy ważne. Opowiadanie, TP 1947, R. 3, nr 14/15, s. 7-8; tenże, Serce, TP 1948, R. 4, nr 52/53, s. 5; tenże, Śnieg, tamże; tenże, Wiatr, tamże; tenże, Wieczory, tamże; tenże, Harmonia Beethovena, tamże; tenże, Wspomnienie, TP 1949, R. 5, nr 42, s. 5; Wiersze Krzysztofa Baczyńskiego (Inedita z teki pośmiertnej), TP 1950, R. 6, nr 51/52, s. 4.

${ }^{38}$ B. Deczkowski, Wspomnienia o pracy dywersyjnej Baczyńskiego, TP 1948, R. 4, nr 36, s. 4-5; K. Konarska-Łosiowa, Pamięci Krzysztofa Baczyńskiego, TP 1949, R. 5, nr 31, s. 7.

39 Jan Dobraczyński ur. 20 kwietnia 1910, zm. 5 III 1994. Uczestnik wojny obronnej 1939 r., i żołnierz AK podczas powstania warszawskiego. Współredaktor pism konspiracyjnych, poseł na sejm 1952-1956 i 1985-1989, 1953-1955 przewodniczący rady redakcyjnej TP. Zob. https://encyklopedia.pwn.pl/haslo/Dobraczynski-Jan;3893252.html (dostęp: 1.12.2020).

40 J. Dobraczyński, Lusia, TP 1946, R. 2, nr 7, s. 5.

41 Wojciech Kętrzyński ur. 1 maja 1918 r. - zm. 2 lipca 1983 r. Historyk, poseł na Sejm 1980-1983 z ramienia Chrześcijańskiego Stowarzyszenia Społecznego. Zob. http://orka. sejm.gov.pl/ArchAll2.nsf/887794e0b4e2e4aac125687200399a4d/bdfcf6d8ff67d9eec125684800323c03?OpenDocument (dostęp: 1.12.2020). 
wybuchu powstania 1 sierpnia dalszy bieg dziejów nie byłby dla stolicy i jego ludności łaskawszy - doszłoby do ewakuacji ludności, a miasto podzieliłoby losy Budapesztu ${ }^{42}$ lub nie doszłoby do ewakuacji, ale wtedy powstanie i tak wybuchłoby, tylko byłoby jeszcze bardziej tragiczne, bo walki toczyłyby się blisko frontu. Kętrzyński nie uważał za szczególnie trafny, upowszechniany już wtedy przez publicystów pogląd o rzekomym podziale warszawiaków na ludzi odpowiedzialnych za wybuch powstania i bohaterskich walczących ${ }^{43}$. W kolejnym tekście, opublikowanym 30 września 1945 r., Kętrzyński pisał o powstaniu jako logicznym elemencie swoistego fatalnego ciągu wydarzeń, ułożonych $\mathrm{w}$ łańcuch przyczynowo-skutkowy ${ }^{44}$. Takie spojrzenie na wydarzenia z powstańczej Warszawy z pewnością wymagało dużego zdystansowania się od tamtej tragedii.

Ostrą polemikę z Kętrzyńskim podjął Stefan Kisielewski ${ }^{45}$. Twierdził on, że każdy warszawiak w przededniu omawianych wydarzeń był przekonany, że zryw będzie nie tylko zwycięski, ale i krótki. Według „Kisiela”, gdyby społeczeństwo znało prawdziwą stawkę podjęcia walki, to i tak przynajmniej 10\% mieszkańców chciałoby rzucić okupantowi rękawicę - byłaby to młodzież, która była tak zaślepiona myślą o zemście, że nie miała możliwości zrozumienia, czym jest ich ojczyzna i służba dla niej, przez co nie wiedziała, czym ryzykuje. Ale w tym wypadku to mniejszość narzuciła swoje zamiary większości. Z tezą, że lwia część mieszkańców była przeciwko zrywowi zbrojnemu, zaś podział na dwie grupy wyznaczało kryterium wieku warszawiaków, całkowicie zgodził się Gołubiew ${ }^{46}$. Dodatkowo - „Kisiel” skonstatował, że jeden z głównych celów powstania - zaznaczenie dążenia do niezależności politycznej Polski - był z góry niemożliwy do wywalczenia - gdyż osiągnięcie wtedy niezależności było zupełnie nierealne. Ponadto właśnie w wyniku powstania, co może się wydawać paradoksalne, Polacy utracili to, co świadczyło o narodowej odrębności: dorobek materialny i warstwę inteligencji. Myśl ta prowadziła autora do wniosków, że naród polski musi jak najszyb-

${ }^{42}$ Bitwa o Budapeszt była jedną z najkrwawszych i najdłuższych bitew II wojny światowej. Zob.: A. Beevor, Druga wojna światowa, Kraków 2015, s. 812-813, 848-849, 851-858; M. Sowa, Budapeszt 1944-1945, Warszawa 2002.

${ }^{43}$ W. Kętrzyński, Warszawa 1944..., s. 1.

${ }_{44}$ Tenże, Historyczne perspektywy, TP 1945, R. 1, nr 28, s. 1-2.

45 Stefan Kisielewski „Kisiel” - publicysta, kompozytor, krytyk muzyczny, ur. 7 marca 1911 r. - zm. 27 września 1991 r. Brał udział w wojnie obronnej 1939 r., po przegranej kampanii wstąpił do AK, brał udział w powstaniu warszawskim. Poseł na Sejm w latach 19571964. Zob. https://encyklopedia.pwn.pl/haslo/Kisielewski-Stefan;3922499.html (dostęp: 1.12.2020).

${ }^{46}$ A. Gołubiew, Myśli o powstaniu warszawskim..., s. 1-2. 
ciej zacząć kreować swoją politykę w oparciu o realizm, gdyż w przeciwnym wypadku jego egzystencja będzie zagrożona ${ }^{47}$.

Bardzo podobne konkluzje pojawiły się też w jedynym z wierszy opublikowanym w omawianym okresie na łamach pisma. Na pierwszym planie uwidoczniona została zapalczywa młodzież podejmująca straceńczą walkę zbrojną ku niemalże radości Niemców. Tym samym autor wiersza dowodził, że żaden rozsądny Polak nie mógł się cieszyć z wybuchu warszawskiej insurekcji ${ }^{48}$.

Z krytyką podziału na chcącą wywołania powstanie "górę" i walczące z obowiązku „doły” nie zgadzała się Starowieyska-Morstinowa ${ }^{49}$, argumentując, że kilka osób z dowództwa AK, nie byłoby w stanie samodzielnie wywołać tak wielkiego ruchu. Jej zdaniem takie twierdzenia były wręcz szkodliwe, bo odrywały naród jako zbiorowość od odpowiedzialności za swoje czyny. Z tym poglądem bardzo mocno polemizował Bocheński twierdząc, że to faktycznie była decyzja tylko pięciu osób, zaś żołnierze AK po prostu rzetelnie wykonali swój rozkaz i nie można ich za to winićs ${ }^{50}$. Ostatni narodowy zryw według Starowieyskiej-Morstinowej w pełni potwierdzał schemat polskich powstań - inspirujące bohaterstwo i męstwo uczestników walk połączone z olbrzymimi stratami materialnymi. Co jednak najsmutniejsze publicystka trafnie zauważała (nie zgadzając się z wcześniejszym stwierdzeniem redakcji „Tygodnika” o „zrozumieniu i podziwie świata” dla Warszawy), że dla świata ta walka nic nie znaczyła, z czym zgadzał się również Kisielewski ${ }^{51}$. Dalej przywołana autorka podkreślała, że w czasach zaawansowanej techniki wojskowej, improwizowane powstania są już przeżytkiem ${ }^{52}$. Teza o niemożliwości zwycięstwa powstańców, pojawiła się również u Gołubiewa, który dodatkowo twierdził, że na bazie wydarzeń w stolicy powstała wspaniała legenda, lecz olbrzymia ofiara miasta i jego mieszkańców, która stanowiła podstawę legendy nie była konieczna ${ }^{53}$.

Kolejny głos redakcji będzie zawierał już inne podejście do opisywanej sprawy. W artykule Po czterech latach ukazywała swoją niechęć do patosu, deklarowała swoją zdolność do podchodzenia do tego jakże bolesnego

47 S. Kisielewski, Porachunki narodowe, TP 1945, R. 1, nr 24, s. 2.

${ }^{48}$ J. Twardowski, Piosenka o powstaniu, TP 1946, R. 2, nr 16, s. 9.

${ }_{49}$ Zofia Starowieyska-Morstinowa - ur. 21 lipca 1891 - zm. 3 lipca 1966, pisarka i publicystka. Współredaktor TP w latach 1945-1953 i od 1957 r. Zob. https://encyklopedia.pwn.pl/ haslo/Starowieyska-Morstinowa-Zofia;3979153.html (dostęp: 1.12.2020).

50 A. Bocheński, $O$ dyskusji nad Monte Cassino, TP 1946, R. 2, nr 45, s. 1, 4.

${ }^{51}$ S. Kisielewski, Most Poniatowskiego - Zagadnienia, TP 1946, R. 2, nr 34, s. 2.

${ }^{52}$ Z. Starowieyska-Morstinowa, Odpowiedzialność, TP 1945, R. 1, nr 30, s. 1-2.

${ }^{53}$ A. Gołubiew, Myśli o powstaniu..., s. 1-2. 
tematu bez większych emocji. Częściowo wpisywano się w ten sposób w oficjalną narrację o przyszłej odbudowie Warszawy, która z pewnością będzie piękniejszym miejscem. Otwarcie jednak stwierdzono, mimo że powstańcy wypełnili swój obowiązek i należy im się za to szacunek, to ów czyn zbrojny nie zmienił losów narodu polskiego ${ }^{54}$.

Ostatni w omawianym okresie, oraz najbardziej gorzki był artykuł Pawła Jasienicy (Leona Lecha Beynara) ${ }^{55}$. Po zaznaczeniu swojego szacunku dla powstańców (autor sam później skrótowo napomknął czemu nie wziął w nim udziału), rozpoczął on bezkompromisową rozprawę z ideą zrywu. Jego twierdzenia, oprócz tezy, że powstanie mogło nie wybuchnąć, zaś argument o nieuchronności owych wydarzeń tylko kompromituję dowódców podziemia. Wspominał również o zarzucaniu defetyzmu wszystkim ludziom, którzy byli swoistymi "głosami rozsądku" nawołującymi do spokoju. Przygotowanie do powstania, mimo wcześniejszych 5 lat okupacji było całkowicie nieprzemyślane i opłakane. Polacy niczego nie nauczyli się z klęski wojny obronnej 1939 r. Na koniec brutalnie stwierdził, że jedną z przyczyn wybuchu powstania było całkowite nieposzanowanie ludności cywilnej i obawa przed brakiem okazji do zdobycia chwały. Nic nie oddaje lepiej ogólnego wydźwięku artykułu, niż przytoczony przez Jasienicę cytat „Powstanie było wymierzone militarnie przeciwko Niemcom, politycznie przeciw Sowietom (demonstracyjnie przeciw Anglosasom, a faktycznie przeciw Polsce - jak dodaje pewien mędrzec)" ${ }^{\prime \prime 6}$.

Oprócz powyższych prób rozliczeń skutków powstania warszawskiego pojawiały się również opisy różnych działań zbrojnych. Zwracano uwagę, że już w pierwszych dniach ponoszono wielkie straty w ludziach, ilość amunicji jaką dysponowali powstańcy, miała wystarczyć tylko na 5-7 dni ${ }^{57}$. Przy tej okazji zwrócono uwagę na mniej znany element insurekcji, jakim były epizody na warszawskiej Pradze. Nie zapominano też o losie ludności, która została wypędzona z miasta po jego kapitulacji. W tym wypadku „Tygodnik” nadmienił chociażby o roli Krakowa w udzielaniu pomocy wysiedlonym warszawiakom ${ }^{58}$. Niestety już wtedy na łamach pisma pojawiały się komu-

54 Po czterech latach, TP 1948, R. 4, nr 31, s. 1.

55 Paweł Jasienica (Leon Lech Beynar) - ur. 10 listopada 1909 - zm. 19 sierpnia 1970, historyk, publicysta. Uczestnik wojny obronnej 1939 r., oficer AK, represjonowany podczas stalinizmu, niezwykle zasłużony popularyzator historii. Zob. https://encyklopedia.pwn.pl/ haslo/Jasienica-Pawel;3917131.html (dostęp: 1.12.2020).

${ }^{56}$ P. Jasienica, Wrzesień i sierpień, TP 1949, R. 5, nr 19, s. 1-3.

57 Temat braków w broni i amunicji pojawia się wielokrotnie: Sanitariuszka „Zosia”, Z Czerniakowa do..., s. 8-9; P. Jasienica, Wrzesień i sierpień..., s. 1-3; Z. Czajkowski, Śmierć Krzysztofa Baczyńskiego, TP 1948, R. 4, nr 28, s. 9.

58 M. Cz., Tułactwo polskie, TP 1945, R. 1, nr 30, s. 6. 
nistyczne mity o aktywnym wsparciu walczącego miasta przez ZSRS, czy to w formie dostarczania powstańcom zrzutów, czy próbach obrony Warszawy przez sowieckie myśliwce przed niemieckimi nalotami, nie wspominając już o rzekomym wsparciu artyleryjskim. Pomoc sowiecką przedstawiano jako olbrzymią, zaś zachodnia była tak skromną, że niemal bez znaczenia. Naturalnie pisano również o udziale tzw. własowców w tłumieniu powstania. Opisywano również naloty na Okęcie i Służewiec. Warto jednak zwrócić uwagę, że wspomniano o udziale $\mathrm{w}$ walce przeciwko powstańcom oddziałów rekrutowanych z ludzi zamieszkujących ZSRS - Kozaków i Ukraińców. Ponadto, mimo iż „wielka pomoc sowiecka” była niczym innym jak mirażem, to twierdzono, że dzięki sabotażom w niemieckich fabrykach dokonywanych przez pracowników będących $\mathrm{w}$ istocie więźniami, przeciętnie co czwarty wrogi pocisk miał okazywać się niewypałem. A niewypały, były cennym źródłem trotylu ${ }^{59}$.

Warto również zwrócić uwagę na przewijające się na kartach pisma komunikaty o zbiórkach pieniędzy na odbudowę stolicy i zwracanie uwagi odbiorców na inicjatywy, mające na celu upamiętnienie tragedii polskiej stolicy. Takimi „cegiełkami” do upamiętnienia hekatomby było udostępnianie ogłoszeń Instytutu Zachodniego, poszukującego zdjęć z powstania (organizacja ta robiła po prostu odbitki zdjęć na swój koszt), promowanie wystawy rysunków Tadeusza Kulisiewicza ukazujące zgliszcza heroicznego miasta (dwa obrazy zamieszczono $w$ gazecie), czy zamieszczanie recenzji książek opisujących minione wydarzenia ${ }^{60}$. Jeśli chodzi o komunikaty traktujące o zbiórkach, mających na celu sfinansowanie odbudowywania stolicy, to oprócz przekazywania informacji o działalności wydawniczej Naczelnej Rady Odbudowy Warszawy, drukowano komunikaty o koniecznych dalszych pracach w zniszczonej stolicy, loteriach fantowych na odbudowę miasta organizowanych przez Radę Prymasowską Odbudowy Kościołów Warszawy, czy zbiórki na Społeczny Fundusz Budowy Stolicy ${ }^{61}$.

Jednak mimo opinii o nieefektywności powstań zbrojnych i niemożliwości zwycięstwa walczących mieszkańców Warszawy pojawił się również

59 L. Kowalczyk, Brulion historii, TP 1945, R. 1, nr 34, s. 3-4; L. Prorok, Powstanie na taśmie..., s. 3-4; Sanitariuszka „Zosia”, Z Czerniakowa do..., s. 3-4; Sanitariuszka „Zosia”, Z Czerniakowa do..., s. 8-9; P. Jasienica, Wrzesień i sierpień..., s. 1-3.

${ }^{60}$ Fotografie z powstania, TP 1947, R. 3, nr 10, s. 9; H. Blumówna, Warszawa 1945 (Rysunki Tadeusza Kulisiewicza), TP 1947, R. 3, nr 20, s. 8; zsm., W piwnicach Warszawy, TP 1949, R. 5, nr 6, s. 9.

${ }^{61}$ Wśród czasopism - Plan odbudowy Warszawy, TP 1947, R. 3, nr 1, s. 15; Z dnia, TP 1949, R. 5, nr 36, s. 3; II wielka loteria fantowa na odbudowę katedry i kościołów Warszawskich, TP 1950, R. 6, nr 2, s. 8, nr 3, s. 2; Loteria na odbudowę kościołów w Warszawie, TP 1950, R. 6, nr 42, s. 11 , nr 43, s. 2 , nr 45, s. 2, nr 46, s. 2, nr 47, s. 2, nr 49, s. 2; $Z$ dnia, TP 1951, R. 7, nr 36, s. 11. 
wątek, z którego wynikało że sami Niemcy doceniali swoich przeciwników. Dowodem na to miało być ustanowienie specjalnego odznaczenia dla żołnierzy biorących udział w tłumieniu powstania ${ }^{62}$.

Bardzo smutną konstatacją, którą można uznać za podsumowanie uwag „Tygodnika Powszechnego" na temat powstania warszawskiego, stanowiło powielane w kilku tekstach otwarte i bardzo brutalne w swojej wymowie stwierdzenie o tym, że po insurekcji Warszawa „umarła” i nawet jeśli zostanie odbudowana, nigdy nie będzie już tym samym miastem ${ }^{63}$. Na szczęście $\mathrm{w}$ tym zakresie redakcja nie miała racji.

Należy zwrócić uwagę, że siłą rzeczy „Tygodnik Powszechny” wpasowywał się do wyznaczonej przez władzę polityki historycznej w poszczególnych latach. Nie sposób nie zauważyć, że od roku 1948 nie opublikowano żadnego tekstu podejmującego rozważania na temat powstania. Wyjątkiem był tekst Pawła Jasienicy wydrukowany w 1949 r. Poza tym ograniczano się do publikowania fragmentów wspomnień, deklaracji redakcji, czy wierszy Baczyńskiego. Na początku lat 50. temat insurekcji warszawskiej praktycznie znika z kart pisma.

Omawiany stosunek „Tygodnika Powszechnego” do powstania warszawskiego nie był jednoznaczny. Po początkowym braku prób wartościowania zagłady stolicy i ukazywaniu jedności narodu, co niestety nie znalazło odzwierciedlenia w później publikowanych wspomnieniach, rozpoczęto właściwe rozliczenie z traumatycznymi wydarzeniami. W publikowanych materiałach widocznie zaniedbano los ludności cywilnej. Nie unikano jednak opisywania trudnych i niezbyt chwalebnych sytuacji. Zdawano sobie sprawę, że propaganda AK nie odzwierciedlała sytuacji. Wyjątkowo dużo miejsca poświęcono kwestiom religijnym i twórczości oraz osobie Krzysztofa Kamila Baczyńskiego. Widocznie rysowały się różnice w redakcji - część osób nie wierzyła w pewny wybuch insurekcji, część sprzeciwiała się komunistycznemu podziału na "górę” i „doły” AK, część wprost uznawała minione wydarzenie było pozbawione jakiegokolwiek sensu. Na koniec należy zwrócić uwagę, że mimo powielania przychylnym komunistom mitów, „Tygodnik Powszechny", drukując masę informacji, ogłoszeń i zaproszeń, czynnie dokładał swoje cegiełki do odbudowy stolicy i utrwalenia pamięci o tragedii polskiej stolicy.

${ }^{62}$ L. Kowalczyk, Brulion historii..., s. 3-4.

${ }_{63}$ J. Osińska, Warszawa maj 1945, TP 1945, R. 1, nr 15, s. 5; A.G., Artur Oppman (Or-Ot). Legendy warszawskie - Nowe książki - Dla dzieci i młodzieży, TP 1946, R. 2, nr 30, s. 7. 


\section{BIBLIOGRAFIA}

\section{Opracowania}

Beevor A., Druga wojna światowa, tłum. G. Siwek, Kraków 2015.

Davies N., Powstanie '44, tłum. E. Tabakowska, Kraków 2014.

Napiórkowski M., Powstanie umarłych. Historia pamięci 1944-2014, Warszawa 2016.

Powstanie w Warszawie. Fakty i dokumenty, b.m.w. 1945.

Sawicki J.Z., Bitwa o prawdę. Historia zmagań o pamięć powstania warszawskiego 1944-1989, Warszawa 2005.

Sawicki J.Z., Pomnik jako pole bitwy, „Roczniki Nauk Społecznych” 2015, t. 7, nr 3.

Sowa M., Budapeszt 1944-1945, Warszawa 2002.

\section{Prasa}

„Rzeczpospolita: organ Polskiego Komitetu Wyzwolenia Narodowego” 1944.

„Tygodnik Powszechny” 1945-1953.

„Tygodnik Solidarność” 1997.

\section{Źródła internetowe}

http://orka.sejm.gov.pl/ArchAll2.nsf/887794e0b4e2e4aac125687200399a4d/bdfcf6d8f-

f67d9eec125684800323c03?OpenDocument (dostęp: 1.12.2020).

https://encyklopedia.pwn.pl/haslo/Dobraczynski-Jan;3893252.html (dostęp: 1.12.2020).

https://encyklopedia.pwn.pl/haslo/Jasienica-Pawel;3917131.html (dostęp: 1.12.2020).

https://encyklopedia.pwn.pl/haslo/Kisielewski-Stefan;3922499.html (dostęp: 1.12.2020).

https://encyklopedia.pwn.pl/haslo/Starowieyska-Morstinowa-Zofia;3979153.html (dostęp: 1.12.2020).

https://www.1944.pl/powstancze-biogramy/jan-mazurkiewicz,30532.html (dostęp: 1.12. 2020). 


\title{
Jakub Kuliś \\ CONSIDERATIONS OF THE WARSAW UPRISING IN “TYGODNIK POWSZECHNY” IN THE YEARS 1945-1953
}

\begin{abstract}
$\mathrm{T}$ he purpose of this article was to present in detail the considerations of "Tygodnik Powszechny" journalists on the Warsaw Uprising. In the realities of post-war Poland, the Catholic view presented by "Tygodnik" was clearly different from the materialistic world view promoted by the authorities at the time. Although the editors of this Christian magazine generally avoided topics related to the fate of ordinary civilians in the Polish capital during these dramatic events, they did not hesitate to raise painful topics. The question of the religiosity of the fighters and the figure of Krzysztof Kamil Baczyński were discussed extensively. Although when describing some themes, e.g. the alleged participation of the Russian Liberation Army in the fights, communist myths were reproduced in the narrative of the uprising, the editors of the weekly discussed vividly among themselves, showing different worldviews in the magazine (e.g. the polemic between Wojciech Kętrzyński and Stefan Kisielewski). In connection with the above, it should be stated that "Tygodnik Powszechny", despite external pressure, approached the subject of the Warsaw Uprising as fully as possible.
\end{abstract}

Keywords: "Tygodnik Powszechny", World War II, Warsaw Uprising, The Republic of Poland, Catholic press. 